\title{
Peran Notaris dalam Mendorong Terciptanya Kepastian Hukum Bagi Investor dalam Investasi Asing
}

\author{
Yusrizal \\ Magister Kenotariatan Fakultas Hukum Universitas Islam Indonesia \\ Jln. Cik Di Tiro No. 1, Yogyakarta, 55223 \\ yuz.ercommunity@gmail.com
}

\begin{abstract}
This study discusses how the role of the notary in encouraging the legal certainty investors in foreign investment with the aim of knowing the extent of the role of the notary in serving foreign investors. This study uses a combination of normative and empirical methods by examining some rules and interviews. The results of the study found that the role of the notary on this issue is limited to making a Company Establishment Deed, Cooperation Agreement, Minutes of General Meeting of Shareholders Substitution of Shareholders, investors can also provide power of attorney to the notary related to the permit management. In all types of notary authority there are also legal consequences for the notary when negligence in making the deed in the form of civil and administrative sanctions.
\end{abstract}

Key words: Investment; investor; notary

\begin{abstract}
Abstrak
Penelitian ini membahas bagaimana peran notaris dalam mendorong terciptanya kepastian hukum bagi investor dalam investasi asing dengan tujuan untuk mengetahui sejauh mana peran notaris dalam melayani investor asing. Penelitian ini gunakan kombinasi metode normatif dan empiris dengan mengkaji beberapa peraturan-peraturan dan juga wawancara. Hasil penelitian ditemukan bahwa peran notaris pada permasalahan ini yaitu hanya sebatas membuat Akta Pendirian Perusahaan, Perjanjian Kerjasama, Berita Acara Rapat Umum Pemegang Saham Pergantian Pemegang Saham, investor dapat pula memberikan kuasa kepada notaris terkait pengurusan izin. Dalam segala jenis kewenangan notaris tersebut terdapat pula konsekuensi hukum bagi notaris apabila melakukan kelalaian dalam pembuatan akta yaitu berupa sanksi perdata dan sanksi administrasi.
\end{abstract}

Kata-kata Kunci: Investasi/penanaman modal; investor; notaris 


\section{Pendahuluan}

Dalam rangka mendorong percepatan pembangunan dan pertumbuhan ekonomi, pemerintah sangat memerlukan kontribusi para investor baik lokal maupun asing. Kontribusi ini dapat dihasilkan melalui lalu lintas ekspor dan impor, terbukanya lapangan pekerjaan baru, masuknya para pakar, ilmu pengetahuan, pendapatan pajak dan masih banyak keuntungan lainnya.

Sebagai tempat untuk melakukan kegiatan investasi, Indonesia memiliki potensi yang sangat besar dan daya tarik tersendiri bagi investor terutama investor asing yang diantaranya : 1

1. Wilayah yang luas dan subur dengan kekayaan alam yang melimpah;

2. Upah buruh yang relatif rendah;

3. Pasar yang sangat besar;

4. Lokasi yang strategis;

5. Adanya upaya sungguh-sungguh dari pemerintah untuk mendorong iklim investasi yang sehat;

6. Tidak adanya pembatasan atas arus devisa, termasuk atas modal dan keuntungan, dan lain-lain.

Bagi investor asing yang ingin berinvestasi di Indonesia, alangkah lebih baik jika terlebih dahulu negara asal investor tersebut telah memiliki Bilateral Investment Treaties (BITs) dengan Indonesia, yaitu perjanjian yang dibuat antara kedua negara yang mengatur mengenai kegiatan investasi di wilayah salah satu negara (negara penerima modal) oleh investor dari negara yang lainnya (negara penanam modal). ${ }^{2}$ BITs juga memuat aturan-aturan di antara kedua negara mengenai bagaimana investasi asing tersebut dapat dilindungi. ${ }^{3}$

Kegiatan penanaman modal dapat dilakukan oleh orang perserorangan maupun badan hukum. Untuk kegiatan penanaman modal dalam negeri seluruh modal harus berasal dari Warga Negara Indonesia, sedangkan untuk kegiatan penanaman modal asing dapat menggunakan sebagaian atau seluruhnya modal asing. Pada umumnya, kegiatan penanaman modal asing dilakukan secara langsung dengan beberapa cara yaitu investor mendirikan perusahaan baru, membeli saham penanam modal lokal sebagian atau seluruhnya (akuisisi), atau

\footnotetext{
${ }^{1}$ Ana Rokhmatussa'dyah, Hukum Investsi \& Pasar Modal, Sinar Grafika, Jakarta, 2017, hlm. 56.

2 Siti Anisah \& Lucky Suryo Wicaksono, Hukum Investasi, UII Press, Yogyakarta, 2017, hlm. 94.

${ }^{3}$ Ibid
} 
pun dengan cara melakukan kerjasama dengan penanam modal lokal (joint venture).

Besaran modal penanam modal pada kegiatan penanaman modal diatur dalam Peraturan Kepala Badan Koordinasi Penanaman Modal Republik Indonesia Nomor 5 Tahun 2013 tentang Pedoman dan Tata Cara Perizinan dan Non Perizinan Penanaman Modal yaitu sebagai berikut: ${ }^{4}$

a. Total investasi lebih besar dari Rp. 10.000.000.000,- (sepuluh miliar rupiah) atau nilai setaranya dalam satuan US Dollar, diluar tanah dan bangunan.

b. Nilai modal ditempatkan sama dengan modal disetor sekurang-kurangnya sebesar Rp. 2.500.000.000, (dua miliar lima ratus juta rupiah) atau nilai setaranya dalam satuan US Dollar.

c. Penyertaan dalam modal perseroan, untuk masing-masing pemegang saham sekurang-kurangnya Rp. 10.000.000,- (sepuluh juta rupiah) atau nilai setaranya dalam satuan US Dollar dan persentase kepemilikan saham dihitung berdasarkan nilai nominal saham.

Apabila telah mengetahui besaran modal, calon penanam modal juga harus mengetahui bidang usaha tertutup dan terbuka bagi investor (Daftar Negatif Investasi) sebab tidak semua bidang usaha terbuka untuk penanam modal, ada beberapa bidang usaha yang tertutup serta pembatasan penyertaan modal bagi investor asing berdasarkan bidang usaha tertentu sebagaimana diatur didalam Peraturan Presiden Nomor 44 Tahun 2016. Calon penanam modal harus memahami dan mengkonsultasikan rencana penanaman modal kepada BKPM selaku instansi yang diberikan kewenangan oleh pemerintah untuk berkonsultasi dan mengurusi investor. Pemerintah juga mengatur serta menjamin penanam modal dalam melakukan kegiatannya melalui Undang-Undang Nomor 25 Tahun 2007 tentang Penanaman Modal. Pemerintah memberikan beberapa kemudahan dan fasilitas bagi penanam modal di Indonesia salah satunya menjamin kepastian hukum bagi investor.

Notaris merupakan salah satu praktisi hukum yang diberikan wewenang oleh hukum untuk membuat Akta Autentik, termasuk di dalamnya pendirian Perseroan Terbatas $^{5}$ yang mengharuskan menggunakan Akta Autentik dalam Bahasa Indonesia untuk mendirikan Perseroan Terbatas. Akan tetapi, masih ada juga kasus

4 Peraturan Kepala Badan Koordinasi Penanaman Modal Nomor 5 Tahun 2013, Pasal 22 ayat (3).

5 Undang-Undang Nomor 40 Tahun 2007 tentang Perseroan Terbatas, Pasal 7. 
notaris yang keliru dalam mengimplementasikan peraturan-peraturan terkait penanaman modal ke dalam Akta Autentik sehingga mengakibatkan Akta pendirian penanam modal dibatalkan oleh pengadilan dalam Putusan Mahkamah Agung Nomor 3042/K/Pdt/2013. Kasus yang pernah terjadi di Batam ini merupakan salah satu bentuk kekeliruan notaris, yang mengakibatkan kerugian bagi para pihak terutama para penanam modal.

Selaku Pejabat Umum yang berwenang untuk membuat Akta Autentik melalu Undang-Undang Nomor 30 Tahun 2004 tentang Jabatan Notaris yang kemudian diperbarui melalui Undang-Undang Nomor 2 Tahun 2014 (UUJN), peran notaris sangat penting dalam mengawal dan memastikan berjalannya Undang-Undang Nomor 25 Tahun 2007 tentang Penanaman Modal, UndangUndang Nomor 40 Tahun 2007 tentang Perseroan Terbatas, Perpres Nomor 44 Tahun 2016 tentang Daftar Bidang Usaha yang Tertutup dan Bidang Usaha yang Terbuka dan peraturan pelaksana lainnya agar sesuai dengan apa yang diinginkan pemerintah dalam memberikan hak penanam modal yaitu kepastian hukum berupa akta autentik dari notaris yang diatur didalam Pasal 14 huruf a UndangUndang Nomor 25 Tahun 2007 tentang Penanaman Modal.

Notaris merupakan jabatan kepercayaan dan telah diamanatkan oleh negara Republik Indonesia untuk mengurus pembuatan Akta Autentik sebagai jaminan kepastian hukum bagi masyarakat termasuk investor. Seharusnya notaris dapat menjaga nama baik dan membantu mewujudkan cita-cita Pemerintah Indonesia untuk mempercepat pembangunan ekonomi nasional melalu Akta Autentik-nya.

Kelalaian notaris ini dapat mempengaruhi minat investor asing untuk masuk ke Indonesia, mengingat penyebaran informasi yang semakin cepat dan akurat di dunia digital sekarang ini. Kesalahan sekecil apapun dapat segera diakses dan diketahui masyarakat luas. Dengan berkembangnya isu-isu negatif terkait penanaman modal di Indonesia akan berdampak pada penurunan jumlah masuknya investor asing ke Indonesia, disebabkan ketidaknyamanan dan kemungkinan terjadi masalah yang sama terhadap Akta Autentik yang dibuat oleh dan/atau di hadapan notaris.

Berdasarkan kasus di atas, penulis tertarik untuk meneliti peran notaris dalam memberikan jasa hukumnya yang berkaitan dengan kegiatan penanaman 
modal asing yang masuk ke Indonesia. Selanjutnya, konsekuensi hukum bagi notaris dalam memberikan jasa hukum yang berkaitan dengan investasi asing yang tidak sesuai dengan ketentuan yang berlaku.

\section{Rumusan Masalah}

Permasalahan yang dipaparkan dalam tulisan ini adalah sebagai berikut. Pertama, bagaimanakah peran notaris dalam mendorong terciptanya kepastian hukum bagi investor dalam investasi asing? Kedua, bagaimana konsekuensi hukum bagi notaris dalam memberikan jasa hukum yang berkaitan dengan investasi asing yang tidak sesuai dengan ketentuan yang berlaku?

\section{Tujuan Penelitian}

Berdasarkan dari permasalahan diatas dapat dirumuskan tujuan dari penelitian ini, pertama, untuk mengkaji secara mendalam Peran Notaris dalam mendorong terciptanya kepastian hukum bagi investor dalam investasi asing. Kedua, untuk menganalisis konsekuensi hukum bagi Notaris dalam memberikan jasa hukum yang berkaitan dengan investasi asing yang tidak sesuai dengan ketentuan yang berlaku.

\section{Metode Penelitian}

Penelitian ini menggunakan metode penelitian kombinasi normatif-empirirs, dimana metode normatif digunakan untuk menganalisis peraturan perundangundangan yang berhubungan dengan pokok permasalahan dan mengambil sumber-sumber yang berasal dari buku-buku perpustakaan yang berhubungan dengan investor asing. Kemudian peneliti juga mengambil data empiris dengan cara mewawancarai 2 (dua) orang notaris dan 1 orang ahli hukum investasi yang pendapatnya akan dianalisis guna menjawab permasalahan.

\section{Hasil Penelitian dan Pembahasan}

Notaris adalah Pejabat Umum yang berwenang untuk membuat Akta Autentik. Notaris berwenang membuat Akta Autentik mengenai semua perbuatan, perjanjian, dan penetapan yang diharuskan oleh peraturan perundang-undangan 
dan/atau yang dikehendaki oleh yang berkepentingan untuk dinyatakan dalam Akta Autentik. ${ }^{6}$

Berdasarkan kewenangannya tersebut diatas, berarti notaris dapat juga membantu investor asing yang berkaitan dengan Akta Autentik yang di mana terdapat perjanjian-perjanjian antara para pihak untuk melakukan kegiatan usaha dalam bentuk badan usaha. Ada dua jenis badan usaha yaitu badan usaha yang berbadan hukum dan tidak berbadan hukum yang ke-semuanya itu didirikan berdasarkan perjanjian para pihak yang dituangkan ke dalam Akta Autentik, di sinilah peran notaris bermain.

\section{Sekilas tentang Investor dan Investasi}

Menurut Kamus Besar Bahasa Indonesia, investor adalah "penanam uang atau modal, orang yang menanamkan uangnya dalam usaha dengan tujuan mendapatkan keuntungan."7 Sedangkan investasi merupakan kegiatan seorang investor menanamkan modalnya pada suatu usaha tertentu. Salah seorang ahli hukum, Komaruddin, memberikan pengertian investasi dalam tiga arti, yaitu :8

1. Suatu tindakan untuk membeli saham, obligasi atau surat penyertaan lainnya;

2. Suatu tindakan membeli barang-barang modal; dan

3. Pemanfaatan dana yang tersedia untuk produksi dengan pendapatan di masa yang akan datang.

Umumnya investasi dikategorikan menjadi dua jenis yaitu real asset dan financial asset. Real asset ialah sesuatu yang bersifat berwujud seperti gedunggedung, kendaran dan sebagainya. Sedangkan financial asset adalah dokumen (surat-surat) klaim tidak langsung pemegangnya terhadap aktiva riil pihak yang menerbitkan sekuritas tersebut. ${ }^{9}$

Pada penanaman modal asing (foreign investment) biasanya dilakukan melalui empat cara, yaitu: ${ }^{10}$

1. Penanaman modal asing secara langsung;

${ }^{6}$ Undang-Undang Nomor 2 Tahun 2014 tentang Jabatan Notaris, Pasal 15.

${ }^{7}$ Kamus Besar Bahasa Indonesia, Edisi Kedua, hlm. 386.

8 Amin Bendar, Hukum Penanaman Modal Asing, Implementasi untuk pertambangan di Indonesia, UII Press, Yogyakarta, 2018, hlm. 51.

${ }^{9}$ Kamaruddin Ahmat, Dasar-dasar Manajemen Investasi, Rineka Cipta, Jakarta, 1996, hlm. 3-4.

10 Amin Bendar, Op. Cit., hlm. 53. 
2. Penanaman modal asing tidak langsung;

3. Membeli saham-saham perusahaan nasional melalui pasar modal (capital market);

4. Penanaman modal asing lewat pemberian pinjaman; dan

5. Penanaman modal asing lewat kontraktual.

\section{Peran Notaris dalam Investasi}

Peran notaris dalam mendorong terciptanya kepastian hukum bagi investor dalam investasi asing yaitu di dalam penanaman modal asing secara langsung adalah dengan memberikan pelayanan hukumnya berupa pembuatan Akta Pendirian Perseroan Terbatas, Berita Acara Rapat Umum Pemegang Saham (RUPS) Peralihan Pemegang Saham, ataupun membuat perjanjian kerjasama dengan penanam modal lokal.

Di katakan penanaman modal asing apabila modal yang digunakan secara keseluruhan berasal dari modal asing atau berpatungan denan penanam modal dalam negeri11 Berpatungan dalam hal ini bukan berarti 50\% modal asing dan 50\% modal dalam negeri, akan tetapi walaupun hanya ada $1 \%$ modal yang berasal dari asing maka status badan hukumnya tetap berupa Penanaman Modal Asing (PMA).

Bentuk usaha berbadan hukum di Indonesia yaitu perseroan terbatas. Perseroan terbatas adalah suatu bentuk perseroan yang didirikan untuk menjalankan suatu perusahaan dengan modal perseroan tertentu yang terbagi atas saham-saham, dan para pemegang saham (persero) ikut serta dengan mengambil satu saham atau lebih dan melakukan perbuatan-perbuatan hukum yang dibuat dengan menggunakan nama bersama, dengan tidak bertanggungjawab sendiri untuk persetujuan-persetujuan perseroan itu (tanggungjawab hanya sebatas pada modal yang disetorkan). ${ }^{12}$

Legalitas dari Perseroan Terbatas terletak pada autentisitas Akta Pendiriannya yang harus dibuat di hadapan seorang notaris. Selain itu, Perseroan Terbatas diwajibkan untuk menyelenggarakan RUPS setiap tahun dan bisa lebih. Untuk mencatatkan segala kegiatan pada saat RUPS untuk kemudian dituangkan ke

11 Undang-Undang Nomor 25 Tahun 2007 tentang Perseroan Terbatas, Pasal 1 ayat (3).

12 C.S.T Kansil, Hukum Perusabaan Indonesia, cetakan kedua, PT. Pradnya Paramita, Jakarta, 1985, hlm. 22. 
dalam Akta Autentik agar dapat menjadi dasar dalam melakukan perbuatan hukum dan sebagai dasar perubahan anggaran dasar suatu perseroan dibutuhkan lagi jasa hukum notaris.

Dalam wawancara yang pertama, peneliti menemui seorang notaris bernama Dyah Maryulina Budi Mumpuni, S.H., M.Kn. yang berkedudukan di Kota Yogyakarta. Notaris Dyah mengatakan bahwa salah satu syarat pokok untuk mendirikan PMA yaitu saham yang dimiliki di dalam perseroan terbatas harus ada kepemilikan Warga Negara Asing (WNA). Kepemilikan ini tidak harus seluruhnya dimiliki oleh asing, akan tetapi bisa sebagain dimiliki warga negara Indonesia (WNI).

Sebelum pendirian, notaris harus memperhatikan paspor orang asing yang menjadi salah satu pemegang saham apakah masih aktif atau sudah kadaluarsa. Pada saat memeriksa dokumen tersebut, notaris harus menggunakan asas kehatihatian dengan mengecek dokumen pada instansi terkait.

Berhubungan dengan usaha yang dijalankan, notaris tidak boleh asal-asalan dalam membuatkan akta pendirian perusahaa, notaris harus memperhatikan domisili industri yang diajukan sebagai tempat mendirikan perusahaan apakah masuk kawasan industri atau tidak. Selain itu, izin dari masyarakat setempat harus lebih diprioritaskan. Pihak asing dapat melakukan sosialisasi terhadap rencana pendirian perusahaan dilingkungan tersebut dengan didampingi dari pihak pemerintah setempat untuk melakukan pendekatan-pendekatan.

Apabila syarat awal tersebut di atas telah terpenuhi, kemudian masuk ke syarat pendirian perseroan terbatas penanaman modal asing. Adapun beberapa syarat yang harus dipenuhi yaitu :

1. Identitas para pemegang saham;

2. Paspor bagi pemegang saham yang berasal dari negara lain;

3. Visa kerja;

4. Bagi investor asing diperlukan kelengkapan dokumen untuk berinvestasi dari negara asalnya;

5. Bidang usaha yang dipilih;

6. Besaran modal;

7. Tempat kedudukan usaha; 
8. Manfaat PMA bagi masyarakat sekitar;

9. Kepemilikan modal dasar berupa persentase dari Perpres Nomor 44 Tahun 2016;

10. Izin prinsip bersama investor sendiri atau dari perusahaan;

11. Pengecekan nama perseroan terbatas secara tentatif selama 60 hari. Dalam waktu 60 hari harus sudah dapat nama dari BKPM;

12. PNBP nama, PNBP ini harus dibayar ke BKPM minimal 3 (tiga) suku kata dalam bahasa Inggris;

13. Akta pendirian perusahaan mencakup pendaftaran perusahaan PMA melalui Pelayanan Terpadu Satu Pintu (PTSP) di BKPM, Nomor Pokok Wajib Pajak (NPWP), pengesahan badan hukum usaha;

14. Izin lingkungan mencakup izin Undang-Undang gangguan, Rekomendasi analisis mengenai dampak lingkungan (AMDAL), izin pengambilan/ pemanfaatan air bawah tanah;

15. Izin perusahaan mencakup Surat Izin Tempat Usaha (SITU), Tanda Terdaftar Perusahaan yang dikeluarkan oleh pemerintah Daerah melalui PTSP daerah oleh Kepala Daerah; dan

16. Khusus hotel ada izin pariwisata sesuai bidang usaha.

Setelah syarat-syarat tersebut diatas telah terpenuhi barulah notaris dapat memintakan pengesahan Perseroan Terbatas PMA tersebut kepada Menteri Hukum dan Hak Asasi Manusia (Kemenkumham). Dalam waktu 30 hari setelah mendapat pengesahan Perseroan Terbatas PMA tersebut harus sudah beroperasi.

Hasil wawancara kedua peneliti dengan seorang ahli hukum investasi Lucky Suryo Wicaksono, S.H., M.Kn. mengatakan bahwa para pemegang saham biasanya lebih memilih cara yang mudah yaitu membeli saham perseroan yang telah berdiri. Cara ini lebih mudah dan cepat dibandingkan dengan mendirikan perseroan yang baru, sebab dapat memakan waktu yang lama. Peran notaris disini ketika penanam modal asing membeli saham perseroan, tentunya perseroan tersebut harus menyelenggaran RUPS dengan agenda perubahan nama pemegang saham yang akan dijadikan dasar perubahan anggaran dasar di dalam akta pendirian perseroan.

Peran notaris harus mencermati secara hati-hati kebenaran identitas, sumber modal dan peraturan lainnya yang berhubungan dengan penanaman modal asing. 
Misalnya pada bidang usaha padi dengan maksimal besaran modal asing maksimal 49\%. Selain itu, notaris juga harus memperhatikan status badan hukum tersebut, jika sebelumnya status badan hukum yang dibeli penanam modal asing itu adalah Penanaman Modal Dalam Negeri (PMDN), maka notaris harus mengajukan perubahan status menjadi Perseroan Terbatas PMA.

Lebih lanjut, Lucky mengatakan bahwa tidak ada aturan yang mengatur notaris untuk mengurusi Perseroan Terbatas PMA, baik itu notaris yang baru diangkat oleh Menteri Hukum dan Hak Asasi Manusia maupun notari senior, semua notaris bisa memberikan pelayanan kepada investor asing.

Pasca pendirian Perseroan Terbatas PMA, notaris tidak bertanggungjawab lagi terhadap pelaksanaan ataupun operasional dari Perseroan Terbatas PMA tersebut, apakah benar-benar dijalankan atau tidak, sebab sebelum pendirian Perseroan Terbatas PMA notaris wajib memberikan penyuluhan hukum terkait kewajiban dan hak dari penanam modal salah satunya seperti mengingatkan mengenai Laporan Kegiatan Penanaman Modal (LKPM). Akan tetapi, apabila dikemudian hari terdapat permasalahan terkait akta yang dibuat notaris seperti halnya pada kasus di Batam, maka notaris dapat dimintai pertanggungjawabannya baik secara perdata maupun secara administrasi.

Peran notaris hanya sebatas membuat akta pendirian Perseroan Terbatas PMA yang sesuai dengan ketentuan peraturan perundang-undangan dan peraturan lainnya. Adapun salah satu syarat untuk menjadi Perseroan Terbatas PMA yaitu para pendiri atau pemegang saham harus mendapatkan izin prinsip dari BKPM, akan tetapi baru-baru ini pemerintah mengeluarkan Peraturan Pemerintah Nomor 24 Tahun 2018 tentang Pelayanan Perizinan Berusaha Terintegrasi secara Elektronik.

Pasal 1 ayat (5) Peraturan Pemerintah No. 25 Tahun 2018 ini mengatakan bahwa perizinan berusaha terintegrasi secara elektronik atau Online Single Submission (OSS). Lembaga OSS adalah perizinan berusaha yang diterbitkan oleh lembaga OSS untuk dan atas nama menteri, pimpinan lembaga, Gubernur, atau Bupati/Walikota kepada pelaku usaha melalui sistem elektronik yang terintegrasi.

Di dalam sistem OSS ini seluruh bentuk perizinan dapat dilakukan melalui OSS. Adapun bentuk perizinan yang dapat didaftarkan melalui OSS yaitu: 
a. Izin usaha (baik perorangan maupun non perseorangan);

b. Komitmen dan tanpa komitmen (izin lokasi, izin lokasi perairan, izin lingkungan, IMB);

c. Nomor Induk Berusaha (NIB);

d. Nomor Pokok Wajib Pajak (NPWP);

e. Tanda Daftar Perusahaan (TDP); dan

f. Rencana Penggunaan Tenaga Kerja Asing (RPTKA).

Berdasarkan hirearki hukum di Indonesia, Peraturan Pemerintah mempunyai kedudukan yang tinggi hanya dibawah Undang-Undang, sehingga semua Peraturan Presiden, Peraturan Menteri, Peraturan Lembaga, Peraturan Kepala Daerah, dan lainnya yang harus tunduk serta menyesuaikan dengan lembaga OSS.

Melalui Peraturan Pemerintah ini, setiap orang dapat mendaftarkan izin untuk melakukan usaha termasuk pengurusan izin perusahaan asing. Sejak berlakunya OSS, pendirian Perseraon Terbatas PMA tidak diperlukan izin prinsip dari BKPM, sehingga para pendiri PMA, melakukan proses yang sama dengan pendirian PMDN, mengajukan perizinan di lembaga OSS, kemudian baru membuat akta notaris serta mendaftarkan pengesahannya pada AHU online.

Adapun alur pendaftaran perizinan usaha terbaru melalui lembaga OSS :

Pelaku Usaha $\Longleftrightarrow$ Notaris (Pendirian Badan usaha) $\Longleftrightarrow$ Kementerian hukum dan HAM - AHU Online $\rightleftarrows$ Pendaftaran kegiatan usaha $\Longrightarrow$ Lembaga OSS

Dengan adanya peraturan pemerintah terbaru ini, peran notaris dalam membantu mendorong terciptanya kepastian hukum bagi investor asing dalam investasi asing sangat berpengaruh besar, sebab notaris dapat mengurus izin prinsip sendiri tanpa melalui BKPM dan dapat langsung menerbitkan akta pendirian Perseroan Terbatas PMA melalui Kementerian Hukum dan HAM.

\section{Tanggung Jawab Hukum bagi Notaris}

Notaris merupakan jabatan kepercayaan sebagaimana yang dikatan UUJN dalam Pasal 16 ayat (1) huruf $f$, notaris juga dianggap menguasai seluruh peraturan perundang-undangan maupun peraturan lainnya yang berkaitan dengan seluruh akta yang telah dibuatnya. Kendati demikian, notaris pernah juga melakukan 
kesalahan pada kasus diatas. Berhubungan dengan kesalahan notaris diatas, notaris tersebut dapat mempertanggungjawabkan kesalahan yang diperbuatnya dihadapan hukum apabila para pihak merasa dirugikan akibat dari kekeliruan notaris yang bersangkutan.

Pada dasarnya semua perbuatan notaris mempunyai pertanggungjawaban, baik itu dalam rangka pembuatan Akta Pendirian Perseroan Terbatas PMA maupun Akta Autentik terkait perjanjian kredit, hutang piutang, jual beli, sewa menyewa, pendirian yayasan, organisasi maupun lainnya notaris bertanggung jawab baik secara perdata maupun secara administratif.

Karena sifatnya notaris bertanggungjawab sendiri atas akta yang dibuatnya, maka notaris juga dapat dituntut secara perdata menurut pasal 1365 Kitab Undangundang Hukum Perdata (KUHPer) yang bunyinya, "tiap perbuatan melawan hukum, yang membawa kerugian kepada orang lain, mewajibkan orang yang karena salahnya menerbitkan kerugian itu, mengganti kerugian tersebut."13

Akta yang dibuat notaris tersebut dapat dibatalkan dan putusan hakim membatalkan akta tersebut, sehingga segala perbuatan yang dilakukan oleh seluruh pengurus perseroan tersebatas tidak mempunyai akibat hukumnya dan harus tanggung renteng. Adapun yang menjadi dasar dibatalkannya akta notaris tersebut disebabkan karena unsur subjektifnya tidak terpenuhi karena salah satu pemegang saham berasal dari luar negeri yaitu dari negara Singapore.

Pasal 1320 KUHPerdata yang mengatur tentang syarat sahnya perjanjian, ada syarat subjektif yaitu syarat yang berkaitan dengan subjek yang mengadakan atau membuat perjanjian, yang terdiri dari kata sepakat dan cakap bertindak untuk melakukan suatu perbuatan hukum. ${ }^{14}$ Pasal 1 ayat (3) Undang-Undang Nomor 25 Tahun 2007 tentang Penanaman Modal dikatakan Penanaman modal asing yaitu kegiatan menanam modal yang dilakukan diwilayah negara Indonesia yang dilakukan oleh penanam modal asing baik menggunakan modal asing sepenuhnya maupun sebagian maupun yang berpatungan dengan penanam modal dalam negeri.

\footnotetext{
${ }^{13}$ Kitab Undang-Undang Hukum Perdata, Pasal 1356.

${ }^{14}$ Habib Adjie, Kebatalan dan Pembatalan Akta Notaris, PT. Refika Aditama, Surabaya, 2011, hlm. 68.
} 
Salah satu notaris yang pernah mengurusi pendirian Perseroan Terbatas PMA yaitu Notaris Muhammad Ibnu Pamungkas mengatakan bahwa notaris yang lalai dalam membuat akta otentik, baik itu Perseroan Terbatas PMA atau bukan, selain dapat dituntut melalui KUHPer, notaris juga dapat dikenakan sanksi yang ada di Pasal 84 UUJN.

Dengan menggunakan pasal-pasal tersebut diatas, para pemegang saham yang merasa dirugikan dapat menuntut kepada notaris yang bersangkutan, sebab notaris bertanggungjawab secara pribadi, itu berarti notaris dapat menggunakan seluruh harta kekayaannya untuk mengganti kerugian. Apabila harta notaris habis guna untuk membayar kerugian dan telah dinyatakan pailit oleh pengadilan, maka notaris tersebut dapat diberhentikan sementara dari jabatannya.

Kepatutan, ketelitian dan sikap hati-hati mewajibkan setiap orang dalam memenuhi kepentingannya memperhatikan kepentingan orang lain. Dalam melaksanakan kepentingan tersebut haruslah memperhatikan norma-norma kepatutan, ketelitian serta sikap hati-hati, sehingga tindakannya tidak boleh membahayakan atau merugikan orang lain. Kerugian yang diderita para pihak adalah akibat dari perbuatan notaris tersebut, sehingga dapat dikatakan bahwa perbuatan notaris yang bersangkutan melanggar hukum. Secara normal, perbuatan notaris yang mengakibatkan timbulnya kerugian, karena notaris dianggap mengetahui atau seharusnya mengetahui keadaan dan regulasi akta yang dibuatnya. ${ }^{15}$

Notaris dalam menjalankan jabatannya mempunyai tanggungjawab moral terhadap profesinya. Menurut Paul F. Camanisch menyatakan bahwa profesi adalah suatu masyarakat moral (moral community) yang memiliki cita-cita dan nilainilai bersama. Kelompok profesi memiliki acuan yang disebut Kode Etik Profesi. Pelanggaran terhadap jabatan notaris pada akhirnya akan menimbulkan pertanggungjawaban bagi pengemban profesi, baik itu bertanggungjawab secara administrasi maupun mengganti kerugian secara perdata, lebih jauh lagi notaris

15 Sjaifurrachman dan Habib Adjie, Aspek Pertanggungjawaban Notaris dalam Pembuatan Akta, Mandar Maju, Bandung, 2011, hlm. 183-185. 
dapat bertanggungjawab secara pidana apabila seorang notaris melanggar KUHP dalam melaksanakan tugas dan jabatannya. ${ }^{16}$

Notaris merupakan Pejabat Umum yang berwenang membuat Akta Autentik dalam menjalankan kewenangannya dapat dibebani pertanggungjawaban atas perbuatannya dalam membuat Akta Autentik yang tidak sesuai dengan ketentuan yang berlaku atau dilakukan secara melawan hukum. Pada penelitian ini akan dibahas 2 bentuk pertanggungjawaban notaris sebagai pejabat umum.

\section{Pertanggungjawaban Notaris secara Perdata}

Pertanggungjawaban perdata sangat erat kaitannya dengan perbuatan melawan hukum dan pengganti kerugian akibat perbuatan yang telah dilakukan seseorang. Selain KUHPerdata, pertanggungjawaban perdata lainnya diatur di dalam Pasal 84 Undang-Undang Nomor 2 Tahun 2014 yang menyebutkan tindakan pelanggaran yang dilakukan oleh Notaris terhadap ketentuan sebagaimana dimaksud dalam Pasal 16 ayat (1) huruf i, Pasal 16 ayat (1) huruf k, Pasal 41, Pasal 44, Pasal 48, Pasal 49, Pasal 50, Pasal 51, atau Pasal 52 yang mengakibatkan suatu akta hanya mempunyai kekuatan pembuktian sebagai akta di bawah tangan atau suatu akta menjadi batal demi hukum dapat menjadi alasan bagi pihak yang menderita kerugian untuk menuntut biaya, ganti rugi, dan bunga kepada Notaris. ${ }^{17}$

Ganti rugi terjadi apabila salah satu pihak dalam melakukan hubungan hukum melakukan kesalahan ataupun kelalaian dalam perjanjian sehingga menimbulkan kerugian bagi pihak lainnya, maka pihak yang dirugikan tersebut berhak untuk menuntut ganti rugi serta biaya-biaya lainnya yang timbul akibat kesalahan dari pihak yang melakukan kesalahan.

Bentuk dari ganti rugi terhadap perbuatan melawan hukum yang dikenal oleh hukum adalah sebagai berikut:
a. Ganti rugi nominal;
b. Ganti rugi kompensasi (compensatory damages);
c. Ganti rugi penghukuman (punitive damage); dan
d. Pertanggungjawaban Notaris secara Administrasi. hlm. 49 .

${ }^{16}$ M. Luthfan Hadi Darus, Hukum Notariat dan Tanggungjawab Jabatan Notaris, UII Press, Yogyakarta, 2017, 17 Undang-Undang Nomor 2 Tahun 2014 tentang Jabatan Notaris, Pasal 84. 
Kata pejabat yang diberikan Undang-undang kepada notaris mempunyai konsekuensi tersendiri di mata hukum administrasi Indonesia. Notaris yang merupakan Pejabat Umum diberikan wewenang untuk memberikan pelayanan publik yang berhubungan dengan hukum terkait pembuatan akta. Secara hukum administrasi, notaris diberikan kewenangan berdasarkan UUJN. Apabila ketentuan ini tidak diindahkan maka akan menimbulkan akibat hukum, akta yang dibuat oleh notaris dapat menjadi akta dibawah tangan dan akta tersebut dapat dibatalkan atau batal demi hukum. ${ }^{18}$

Mengenai persoalan pertanggungjawaban pejabat menurut Kranenburg dan Vegting ada dua teori yang melandasinya yaitu:

a. Teori fautes personalles, yaitu teori yang menyatakan bahwa kerugian terhadap pihak ketiga dibebankan kepada pejabat yang karena tindakannya itu telah menimbulkan kerugian.

b. Teori fautes de services, yaitu teori yang menyatakan bahwa kerugian terhadap pihak ketiga dibebankan pada instansi dari pejabat yang bersangkutan. Dalam penerapannya, kerugian yang timbul itu disesuaikan pula apakah kesalahan yang dilakukan itu merupakan kesalahan berat atau kesalahan ringan, dimana berat dan ringannya suatu kesalahan berimplikasi pada tanggungjawab yang harus ditanggung. ${ }^{19}$

Pertanggungjawaban notaris secara administrasi dapat dilihat pada Pasal 85 Undang-Undang Jabatan Notaris yang mengatakan pelanggaran ketentuan sebagaimana dimaksud dalam Pasal 7, Pasal 16 ayat (1) huruf a, Pasal 16 ayat (1), huruf b, Pasal 16 ayat (1) huruf c, Pasal 16 ayat (1) huruf d, Pasal 16 ayat (1) huruf e, Pasal 16 ayat (1) huruf f, Pasal 16 ayat (1) huruf g, Pasal 16 ayat (1) huruf h, Pasal 16 ayat (1) huruf i, Pasal 16 ayat (1) huruf j, Pasal 16 ayat (1) huruf k, Pasal 17, Pasal 20, Pasal 27, Pasal 32, Pasal 37, Pasal 54, Pasal 58, Pasal 59, dan/atau Pasal 63, dapat dikenai sanksi berupa:
a. Teguran lisan;
b. Teguran tulisan;
c. Pemberhentian sementara;
d. Pemberhentian dengan hormat; dan
e. Pemberhentian tidak hormat. ${ }^{20}$

\footnotetext{
${ }^{18}$ M. Luthfan Hadi Darus, Op. Cit., hlm. 54.

${ }^{19} \mathrm{Ibid}, \mathrm{hlm} .57$.

${ }^{20}$ Undang-Undang Nomor 2 Tahun 2014 tentang Jabtan Notaris, Pasal 85.
} 
Sebagaimana yang dikemukakan Paul F. Camanisch sebelumnya, notaris mempunyai pengaturan mengenai kode etik tersendiri yaitu Kode Etik Notaris (KEN) telah mengalami perubahan melalui Kongres Luar Biasa Ikatan Notaris Indonesia di Banten, pada tanggal 29-30 Mei 2015. Di dalam peraturan KEN tersebut terdapat kewajiban mengenai sikap, perilaku, perbuatan atau tindakan notaris. Selain itu juga diatur mengenai larangan-larangan bagi notaris dan juga sanksi bagi notaris yang melanggar peraturan KEN.

Jika notaris melakukan kesalahan terkait akta yang dibuatnya, sehingga dapat merugikan penghadap maka notaris dapat dituntut secara perdata untuk mengganti segala biaya yang timbul akibat kesalahan notaris tersebut.

Secara tidak langsung pasal diatas menuntut tanggungjawab notaris dalam menjalankan tugas jabatannya ketika membuat Akta Autentik. Ketika pengangkatan, notaris disumpah untuk taat dan patuh terhadap peraturan serta siap diberikan sanksi dan mampu bertanggungjawab terhadap tugas dan wewenangnnya sebagai pejabat umum untuk membuat Akta Autentik.

\section{Penutup}

Peran notaris dalam mendorong terciptanya kepastian hukum bagi investor dalam investasi asing hanya sebatas membuat Akta Pendirian Perseroan Terbatas Penanaman Modal Asing. Pada saat pendiriannya, notaris harus memastikan apakah izin prinsip telah disetujuai atau belum baru. Kemudian memeriksa identitas dan sumber modal para investor. Setelah notaris memastikan bahwa identitas dan modal yang dimiliki oleh investor asing tersebut benar-benar berasal dari luar negara Republik Indonesia, maka notaris dapat menentukan bahwa perseroan tersebut berbentuk Perseroan Terbatas Penanaman Modal Asing. Maka dari itu para notaris seharusnya menerapkan asas kehati-hatian dalam menuangkan peraturan perundang-undangan ke dalam akta otentik, sebab notaris mempunyai resiko pada setiap akta yang dibuatnya.

Konsekuensi notaris dalam memberikan jasa pelayanan hukum bagi investor asing terkait Akta Pendirian Perseroan Terbatas berupa tanggung jawab perdata dan tanggung jawab administrasi. Tanggung jawab tersebut, berlaku bagi notaris seumur hidupnya meskipun notaris yang bersangkutan telah pensiun dari 
jabatannya. Tanggungjawab administrasi yaitu apabila notaris dalam menjalankan jabatannya tidak sesuai dengan ketentuan peraturan perundang-undangan, sedangkan tanggungjawab perdata yaitu apabila dalam menjalankan jabatannya notaris melakukan kesalahan ataupun kelalaian. Apabila ada kesalahan terkait pembuatan akta, maka para pihak yang merasa dirugikan terkait kesalahan notaris dalam pembuatan akta dapat menggugat notaris kepengadilan dan meminta ganti rugi. Selain itu, konsekuensi yang dapat diemban notaris, yaitu notaris dapat dipecat atau diberhentikan dari jabatannya berdasarkan permohonan para pihak yang dapat diajukan ke Majelis Pengawas Notaris. Oleh sebab itu, notaris harus selalu mengikuti perkembangan peraturan-peraturan yang terbaru, mempelajari, memahaminya dan mengikuti pelatihan-pelatihan yang diselenggarakan oleh organisasi notaris, juga mengkonsultasikannya kepada senior yang telah berpengalaman di bidangnya.

\section{Daftar Pustaka}

\section{Buku}

Adjie, Habib, Kebatalan dan Pembatalan Akta Notaris, PT. Refika Aditama, Surabaya, 2011.

Ahmat, Kamaruddin, Dasar-dasar Manajemen Investasi, Rineka Cipta, Jakarta, 1996.

Anisah, Siti \& Lucky Suryo Wicaksono, Hukum Investasi, UII Press, Yogyakarta, 2017.

Bendar, Amin, Hukum Penanaman Modal Asing, Implementasi untuk pertambangan di Indonesia, UII Press, Yogyakarta, 2018.

Darus, M. Luthfi Hadi, Hukum Notariat dan Tanggungjawab Jabatan Notaris, UII Press, Yogyakarta, 2017

Kansil, C.S.T., Hukum Perusahaan Indonesia, PT. Pradnya Paramita, Jakarta,1985.

Rokhmatussa'dyah, Ana, Hukum Investsi \& Pasar Modal, Sinar Grafika, Jakarta, 2017.

Sjaifurrachman \& Habib Adjie, Aspek Pertanggungjawaban Notaris dalam Pembuatan Akta, Mandar Maju, Bandung, 2011.

\section{Peraturan Perundang-Undangan}

Kitab Undang-Undang Hukum Perdata

UU No. 25 Tahun 2007 tentang Penanaman Modal sebagaimana telah diubah dengan Undang-Undang Nomor 11 Tahun 1970 tentang Perubahan dan 
Tambahan Undang-Undang Nomor 1 Tahun 1967 tentang Penanaman Modal Asing dan Undang-Undang Nomor 6 Tahun 1968 tentang Penanaman Modal Dalam Negeri, LN 2007, No. 67, TLN No. 4724.

UU No. 40 Tahun 2007 tentang Perubahan atas UU No. 1 Tahun 1995 tentang Perseroan Terbatas, LN 2007, No. 106, TLN No. 4756.

UU No. 2 Tahun 2014 tentang Perubahan atas UU No. 30 Tahun 2004 tentang Jabatan Notaris, LN 2014, No. 117, TLN No. 5491.

Peraturan Pemerintah No. 24 Tahun 2018 tentang Pelayanan Perizinan Berusaha Terintegrasi Secara Elektronik, LN 2018, No. 90, TLN No. 6215.

Peraturan Kepala BKPM Nomor 5 Tahun 2013 tentang Pedoman dan Tata Cara Perizinan dan Nonperizinan Penanaman Modal, BN 2013, No. 584 